\title{
PENERAPAN MODEL PEMBELAJARAN KOOPERATIF TIPE TS-TS PADA MATA KULIAH STRUKTUR ALJABAR
}

\author{
Rahmita Yuliana Gazali \\ Program Studi Pendidikan Matematika STKIP PGRI Banjarmasin \\ rahmitayulianagazali@stkipbjm.ac.id
}

\begin{abstract}
Abstrak: Penelitian ini merupakan penelitian deskriptif kuantitaif untuk menggambarkan atau menjelaskan secara sistematis, faktual dan akurat mengenai fakta dan sifat populasi tertentu. Teknik pengumpulan data menggunakan lembar kerja kelompok melihat pemahaman mahasiswa tentang konsep grup dan sifat-sifatnya, lembar observasi untuk mengetahui capaian keterlaksanaan pembelajaran dengan model pembelajaran kooperatif tipe Two Stay-Two Stray (TS-TS), serta lembar observasi aktivitas mahasiswa. Sedangkan teknik analisis data dengan persentase. Hasil penerapan model pembelajaran kooperatif tipe Two Stay-Two Stray (TS-TS) pada mata kuliah struktur aljabar di materi grup dan sifat-sifatnya menunjukkan: (1) terlaksananya semua sintaks pada pembelajaran dengan model pembelajaran kooperatif tipe TS-TS (2) Memberikan pemahaman yang lebih mendalam tentang konsep grup dan sifat-sifatnya dikarenakan karakteristik sistem kandang (stay) dan tandang (stray) yang memungkinkan mahasiswa untuk bertanya dan menjelaskan secara tidak langsung dapat memperdalam pemahaman tentang konsep yang dipelajari; (3) Memperbanyak variasi aktivitas yang dilakukan mahasiswa saat perkuliahan, tidak hanya sekadar mencatat, mendengarkan penjelasan dosen, tetapi sharing bertanya jawab dengan teman maupun anggota kelompok.

Kata Kunci: Pembelajaran Kooperatif, TS-TS, struktur aljabar
\end{abstract}

Matematika merupakan ilmu universal yang berguna bagi kehidupan manusia, yang erat kaitannya dengan operasi dan konsep. Dalam pembelajaran matematika di level sarjana, mahasiswa diharapkan dapat memahami dan menguasai konsep-konsep matematika tersebut. Makna dari kata "menguasai" di sini adalah mahasiswa seyogyanya tidak sekadar menghafal dan tahu tentang konsep-konsep yang dipelajari di berbagai mata kuliah. Namun, mahasiswa diharapkan mampu mengerti dan memahami tentang suatu konsep serta mampu mengaitkan antara konsep yang satu dengan konsep yang lain untuk menyelesaikan masalah.

Terkait dengan pemahaman seorang individu terhadap suatu konsep yang notabene merupakan hasil dari aktivitas mental tiap individu, Skemp (1976, hal. 25) berpendapat bahwa "to understand something means to assimilate it into an aprrioriate schema". Maknanya bahwa seseorang dapat dikatakan "paham" atau "memahami" sesuatu apabila telah terjadi pengintegrasian informasi baru dengan skema dan pengalaman yang telah dimiliki sebelumnya. Dengan kata lain, aspek pemahaman berkaitan dengan kemampuan (ability) yang dimiliki individu.

Selain pentingnya pemahaman konsep lebih dalam bagi mahasiswa di tiap mata kuliah, juga penting memperhatikan bagaimana fleksibilitas/keluwesan dalam konteks aktivitas mahasiswa selama mengikuti perkuliahan. Aktivitas yang dimaksud adalah bagaimana mahasiswa dalam memperhatikan penjelasan dosen baik terkait materi 
perkuliahan, tugas, aturan main selam proses perkuliahan, maupun penyampaian hal lainnya.

Menurut Amir \& Kurniawan (2016, hal. 15), ada empat akar masalah di tingkat mahasiswa baik selama proses pembelajaran (kuliah) maupun setelah evaluasi pembelajaran (penilaian), yaitu (1) mahasiswa mengalami kesalahan dalam pemahaman konsep; (2) aktivitas mahasiswa selama pembelajaran kurang optimal; (3) minat belajar matematika mahasiswa rendah; (4) interaksi antar mahasiswa kurang optimal. Dugaan bahwa keempat masalah tersebut ada pada saat dilangsungkan perkuliahan struktur aljabar, bisa saja terjadi mengingat mata kuliah struktur aljabar merupakan salah satu mata kuliah di program studi pendidikan matematika yang banyak mencakup banyak konsep, meskipun garis besarnya hanya dua yaitu konsep grup dan ring.

Menurut Arnawa (2009, hal. 62), struktur aljabar atau aljabar abstrak merupakan mata kuliah yang masuk kategori sulit untuk dipelajari dan sulit untuk diajarkan. Jika dilihat dari sisi mahasiswa, kesulitan tersebut muncul disebabkan oleh konsep-konsep dalam aljabar abstrak sangat abstrak, banyak contoh-contoh yang berkenaan dengan konsep, tidak dikenal baik oleh mahasiswa, banyak mahasiswa yang belum terbiasa dengan pembuktian deduktif. Di sisi lain, banyak mahasiswa di perguruan tinggi yang mempunyai penguasaan konsep matematika dan aljabar yang lemah. Hal tersebut disebabkan sikap negatif mereka terhadap materi ketika belajar di sekolah menengah. Mereka hanya menghafal algoritma atau prosedur tetapi tidak memahami konsep yang seharusnya pada tiap prosedur yang digunakan.

Mengacu pada kurikulum yang diterapkan di program studi pendidikan matematika STKIP PGRI Banjarmasin, mata kuliah struktur aljabar dijadwalkan pada semester VI dengan bobot 4 sks, dengan dua konsep besar membahas tentang grup dan ring. Sebenarnya sudah tepat jika mata kuliah struktur aljabar dijadwalkan di semester VI dengan harapan logika dan penalaran mahasiswa untuk memahami konsep yang lebih abstrak dan menghubungkan dengan konsep dan pengetahuan yang sudah diperoleh sebelumnya (mata kuliah prasyarat) sudah terbentuk, sehingga tidak terlalu sulit untuk mengerti dan memahami.

Berdasarkan hasil observasi awal sebelum peneliti mengampu mata kuliah struktur aljabar (sudah mengampu mata kuliah lain sebelum semester VI di kelas yang menjadi sampel penelitian), secara pemahaman memang ada beberapa mahasiswa yang tingkat pemahamannya relatif tinggi, tetapi mayoritas masih dalam tingkat sedang ke rendah. Begitupun dengan aktivitas mahasiswa yang cenderung pasif menerima penjelasan dosen, hanya beberapa yang terlihat aktif dalam memberikan tanggapan saat diskusi pembelajaran berlangsung. Sehingga perlu diterapkan model pembelajaran tertentu untuk mengetahui bagaimana pemahaman mahasiswa terkait materi grup dan bagaimana pula aktivitas mereka selama perkuliahan berlangsung.

Dalam pembelajaran mata kuliah struktur aljabar pada materi Grup dan sifatsifatnya, dua dari empat akar masalah yang dikemukakan Amir \& Kurniawan (2016, hal. 15), yaitu kurangnya pemahaman konsep dan kurang optimalnya aktivitas mahasiswa, dapat peneliti atasi melalui penerapan model pembelajaran Two-Stay Two-Stray (TS-TS). Meskipun tujuan dalam penelitian ini hanya mendeskripsikan bagaimana pemahaman mahasiswa terkait konsep grup dan aktivitas mereka selama perkuliahan, tetapi jika berpatokan dari hasil tugas struktur aljabar 
tentang grup dan sifat-sifatnya, serta hasil observasi peneliti saat pembelajaran dengan TS-TS berlangsung, maka bisa dikatakan bahwa melalui model pembelajaran TS-TS mampu memperjelas pemahaman mahasiswa tentang konsep grup dan memperbaiki aktivitas mahasiswa saat pembelajaran.

Model pembelajaran kooperatif tipe Two Stay Two Stray (TSTS) dikembangkan oleh Spencer Kagan. Model pembelajaran ini bisa digunakan dalam semua mata pelajaran atau mata kuliah dan untuk semua tingkatan usia peserta didik, termasuk mahasiswa. Model pembelajaran kooperatif tipe Two Stay Two Stray merupakan sistem pembelajaran kelompok dengan tujuan agar seseorang (mahasiswa) dapat saling bekerja sama, bertanggung jawab, saling membantu memecahkan masalah dan saling mendorong untuk berprestasi. Model pembelajaran ini juga melatih siswa untuk bersosialisasi dengan baik (Yusritawati, 2009, hal. 14).

Model pembelajaran kooperatif tipe Two Stay Two Stray merupakan model dua tinggal dua tamu, secara berkelompok untuk mendiskusikan mengenai suatu hal yang telah ditentukan oleh seseorang, dalam hal ini dosen. Menurut Suprijono (2009, hal. 93), pembelajaran dengan model ini diawali dengan pembagian kelompok. Setelah kelompok terbentuk dosen memberikan tugas berupa permasalahan-permasalahan yang harus mereka diskusikan jawabannya. Setelah diskusi intrakelompok usai, dua orang dari masing-masing kelompok meninggalkan kelompoknya untuk bertamu kepada kelompok yang lain. Anggota kelompok yang tidak mendapat tugas sebagai tamu mempunyai kewajiban menerima tamu dari suatu kelompok. Tugas mereka adalah menyajikan hasil kerja kelompoknya kepada tamu tersebut. Dua orang yang bertugas sebagai tamu diwajibkan bertamu kepada semua kelompok. Jika mereka telah usai menunaikan tugasnya, mereka kembali ke kelompoknya masingmasing. Setelah kembali ke kelompok asal, baik peserta didik yang bertugas bertamu maupun mereka yang bertugas menerima tamu mencocokkan dan membahas hasil kerja yang telah mereka tunaikan. Dengan kata lain, pada tahap awal sebelum pelaksanaan penelitian, dosen menyiapkan tugas untuk mahasiswa dan membagi mahasiswa menjadi beberapa kelompok dengan masing-masing anggota 4 orang dan setiap kelompok, heterogen.

Dalam penelitian ini pemahaman konsep

meliputi dua indikator yaitu

Menjelaskan/menyatakan ulang sifat tertutup, asosiatif, elemen identitas, invers dari suatu himpunan; (2) Mengidentifikasi suatu himpunan berikut definisi operasinya berdasarkan alasan yang logis. Sedangkan untuk aktivitas mahasiswa dalam penelitian ini meliputi enam indikator yaitu Memperhatikan penjelasan dosen; (2) Bertanya kepada dosen atau teman selama proses pembelajaran dan diskusi; (3) Bertanya kepada teman selama proses pembelajaran dan diskusi; (4) Mengerjakan tugas secara kelompok dan ikut berdiskusi; (5) Berpartisipasi dalam sistem kandang (stay) dan atau tandang (stray); (6) Mempresentasikan hasil kerja kelompok

\section{Metode Penelitian}

Penelitian ini adalah penelitian deskriptif. Penelitian deskriptif (descriptive research) adalah penelitian yang dilakukan untuk menggambarkan atau menjelaskan secara sistematis, faktual dan akurat mengenai fakta dan sifat populasi tertentu. Peneliti menggambarkan suatu gejala (fenomena), atau sifat tertentu, tidak untuk mencari atau menerangkan keterkaitan antarvariabel. 
Penelitian hanya melukiskan atau menggambarkan apa adanya (Sanjaya, 2013, hal. 1), dalam angka-angka dan persentase, sehingga jenisnya adalah deskriptif kuantitatif.

Populasi dalam penelitian ini adalah mahasiswa kelas 31 semester VI dan mahasiswa yang mengulang mata kuliah struktur aljabar, yang berjumlah 30 orang. Sampel dalam penelitian ini dipilih secara acak dengan menggunakan tabel sampel Krejcie. Dari tabel tersebut diperoleh dinyatakan bahwa untuk populasi 30 maka minimal sampelnya 28, artinya jumlah minimum 28 orang mahasiswa sebagai sampel, terpenuhi (ikut penelitian).

Teknik pengumpulan data dengan melakukan metode tes berupa tugas kelompok, observasi, dan dokumentasi. Metode tes digunakan untuk mendapatkan data tertulis berupa hasil diskusi kelompok tentang jawaban 21 soal mengenai grup dan sifat-sifatnya, dari mahasiswa untuk melihat pemahaman mahasiswa tentang konsep grup. Observasi digunakan untuk mengamati aktivitas mahasiswa terutama keterlaksanaan pembelajaran TS-TS, 1 orang observer teman sejawat dosen. Dokumentasi sebagai penegas pelaksanaan sintaks/langkah-langkah TS-TS.

Teknik analisis data menggunakan persentase, dengan rumus:

$$
P=\frac{f}{N} \times 100 \%
$$

Dengan:

P : Persentase

$\mathrm{f}$ : frekuensi

$\mathrm{N}$ : Jumlah responden

\section{Hasil Penelitian dan Pembahasan Hasil \\ A. Keterlaksanaan Perkuliahan dengan Model Pembelajaran Kooperatif tipe TS-TS}

Penelitian ini dilaksanakan pada perkuliahan 31 Maret dan 3 April 2017, dengan total durasi 200 menit: (a) @ 40 menit untuk menjelaskan materi dan aturan main (perkuliahan dengan menerapkan model pembelajaran kooperatif tipe TS-TS); (b) @ 60 menit untuk diskusi dan presentasi kelompok.

Langkah-langkah

model pembelajaran kooperatif tipe TS-TS pada penelitian ini yaitu:

1. Dosen membagi mahasiswa dalam beberapa kelompok yang setiap kelompoknya terdiri dari 4 mahasiswa. Kelompok yang dibentuk merupakan kelompok heterogen dengan tujuan untuk memberikan kesempatan pada mahasiswa untuk saling membelajarkan (Peer Tutoring) dan saling mendukung. Pada penelitian ini ada 7 kelompok dengan distribusi tiap kelompok 4 orang.

2. Dosen memberikan penjelasan terkait grup dan sifat-sifatnya, kemudian memberikan lembar kerja kelompok ke setiap kelompok berupa tugas yang terdiri atas 21 soal untuk mengidentifikasi apakah termasuk grupoid, semigrup, monoid, atau grup.

3. Mahasiswa bekerja sama dalam kelompok. Hal ini bertujuan untuk memberikan kesempatan kepada mahasiswa untuk dapat terlibat secara aktif dalam proses berpikir.

4. Setelah selesai, dua orang dari masing-masing kelompok meninggalkan kelompoknya untuk bertamu ke kelompok lain. Struktur Two Stay Two Stray yang dimaksud tampak seperti pada ilustrasi berikut:

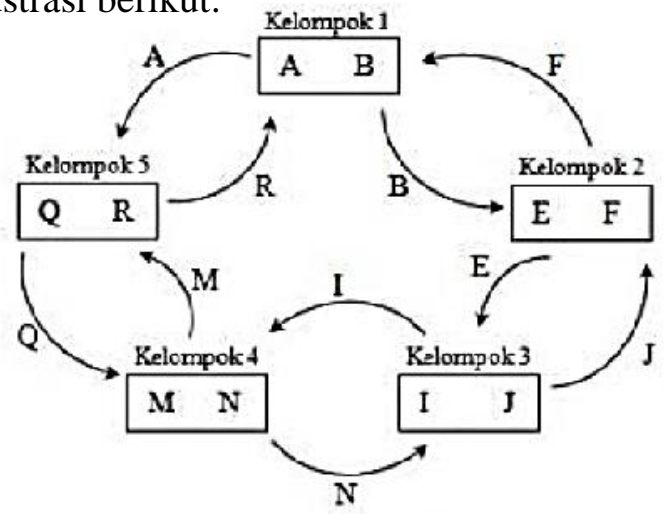

Struktur TS-TS (Yusritawati, 2009, hal. 14) 
5. Dua orang yang tinggal dalam kelompok bertugas membagikan hasil kerja dan informasi mereka ke tamu mereka.

6. Tamu mohon diri dan kembali ke kelompok mereka sendiri dan melaporkan temuan mereka dari kelompok lain.

7. Kelompok mencocokkan dan membahas hasil-hasil kerja mereka.

8. Masing-masing kelompok mempresentasikan hasil kerja mereka.

Secara keseluruhan (8 langkah) model pembelajaran kooperatif tipe TS-TS pada penelitian ini, keterlaksanaannya tersaji pada Tabel 1., sebagai berikut:

Tabel 1. Keterlaksanaan Perkuliahan dengan

Model Pembelajaran Kooperatif Tipe TS-TS

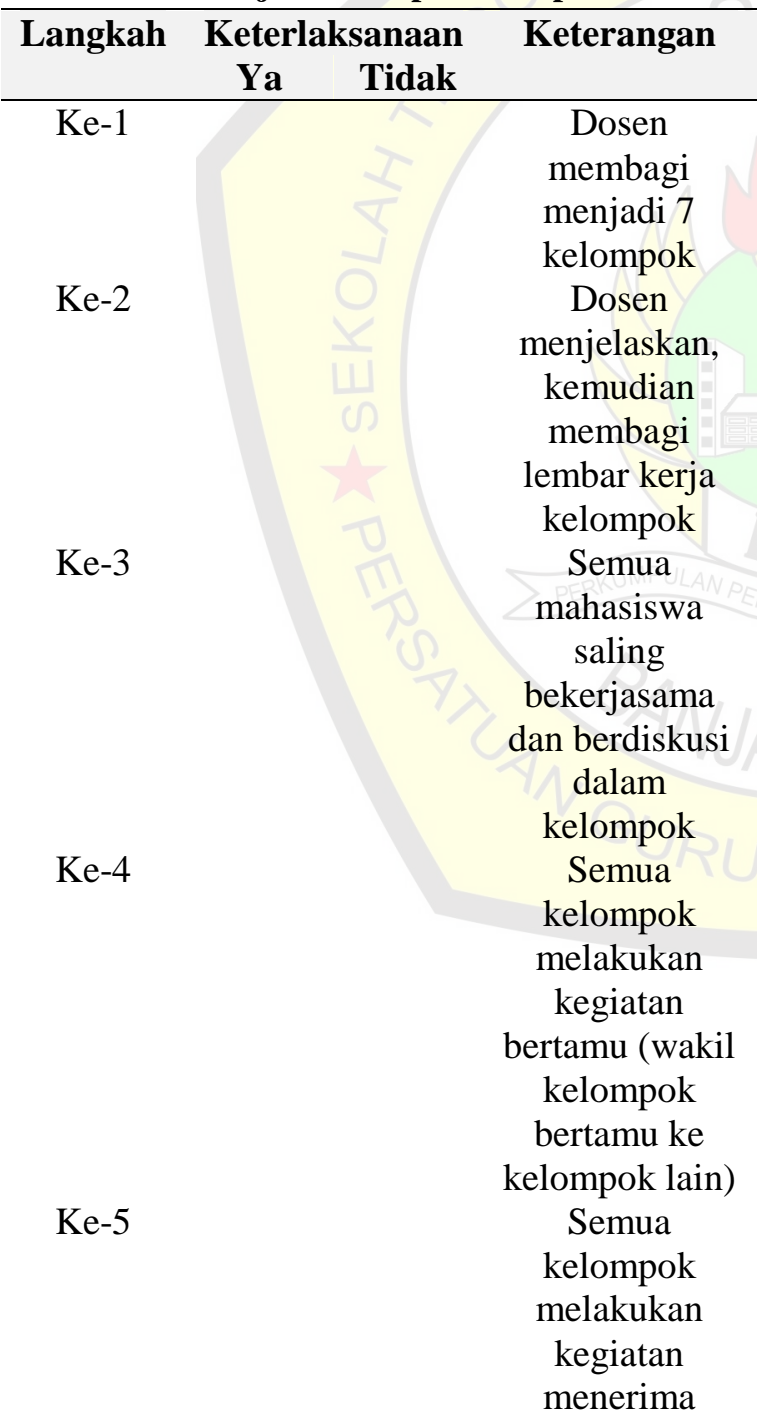

tamu dari

kelompok lain

Semua

kelompok

melaporkan

hasil dari

bertamu

$\mathrm{Ke}-7 \quad \sqrt{ }$

Semua

kelompok

mencocokkan

dan membahas

hasil kerja

Perwakilan

kelompok

Dengan kata lain, semua langkah dalam model pembelajaran kooperatif tipe TS-TS terlaksana $100 \%$. Hanya saja karena keterbatasan waktu, untuk langkah ke- 8 hanya beberapa kelompok yang mempresentasikan hasil kerja mereka.

\section{B. Pemahaman Mahasiswa tentang Grup dan sifat-sifatnya}

Perihal pemahaman mahasiswa tentang konsep grup dan sifat-sifatnya, ditinjau dari hasil diskusi jawaban tugas sebanyak 21 nomor. Tugas yang dimaksud dalam penelitian ini adalah secara berkelompok, mahasiswa diminta untuk mendiskusikan, memberikan jawaban disertai dengan alasan mengapa mengidentifikasi kasus pada tugas disebut grupoid atau semigrup atau monoid atau grup, sesuai dengan keempat aksioma yang sudah dijelaskan oleh dosen pada saat perkuliahan.

Darminto (2009, hal. 108) menyebutkan bahwa pemahaman konsep merupakan kompetensi yang dimiliki mahasiswa dengan beberapa indikator berikut: (1) menyatakan atau menjelaskan ulang sebuah konsep, (2) mengklasifikasikan sifatsifat tertentu, (3) memberi contoh, (4) merepresentasikan konsep, (5) menggunakan 
konsep untuk menyelesaikan masalah. Dalam penelitian ini indikator pemahaman konsep yang dimiliki mahasiswa meliputi: (1) Menjelaskan/menyatakan ulang sifat tertutup, asosiatif, elemen identitas, invers dari suatu himpunan; (2) Mengidentifikasi suatu himpunan berikut definisi operasinya apakah termasuk grupoid, semigrup, monoid, atau grup, berdasarkan alasan yang logis.

Hasil penelitian tentang pemahaman mahasiswa perihal grup dan sifat-sifatnya, sesuai indikator, disajikan pada Tabel 2 . sebagai berikut:
Kelompok

3: $100 \%$

benar dan logis

Kelompok 4: $100 \%$ benar dan logis

Kelompok 5: $67,7 \%$ benar dan logis

Kelompok 6: $67,7 \%$ benar dan logis

Kelompok 7: $67,7 \%$ benar dan

Tabel 2. Rata-rata Persentase Pemahaman Mahasiswa tentang Grup dan sifat-sifatnya

\begin{tabular}{|c|c|c|}
\hline Indikator & $\begin{array}{l}\text { Rata- } \\
\text { rata } \\
\%\end{array}$ & Keterangan \\
\hline $\begin{array}{l}\text { Menjelaskan/menyatakan } \\
\text { ulang sifat tertutup, } \\
\text { asosiatif, elemen } \\
\text { identitas, invers dari } \\
\text { suatu himpunan }\end{array}$ & 91,1 & $\begin{array}{c}\text { Kelompok } \\
\text { 1: } 90,4 \% \\
\text { benar } \\
\text { Kelompok } \\
\text { 2: } 95,2 \% \\
\text { benar } \\
\text { Kelompok } \\
\text { 3: } 85,7 \% \\
\text { benar } \\
\text { Kelompok } \\
\text { 4: } 100 \% \\
\text { benar } \\
\text { Kelompok } \\
\text { 5: 90,4\% } \\
\text { benar } \\
\text { Kelompok } \\
\text { 6: } 85,7 \% \\
\text { benar } \\
\text { Kelompok } \\
\text { 7: 90,4 \% } \\
\text { benar }\end{array}$ \\
\hline $\begin{array}{l}\text { Mengidentifikasi suatu } \\
\text { himpunan berikut } \\
\text { definisi operasinya } \\
\text { berdasarkan alasan yang } \\
\text { logis }\end{array}$ & 86,2 & $\begin{array}{c}\text { Kelompok } \\
\text { 1: } 100 \% \\
\text { benar dan } \\
\text { logis } \\
\text { Kelompok } \\
\text { 2: } 100 \% \\
\text { benar dan } \\
\text { logis }\end{array}$ \\
\hline
\end{tabular}

logis

Dari 21 nomor tugas untuk (1)

Menjelaskan/menyatakan ulang sifat tertutup, asosiatif, elemen identitas, invers dari suatu himpunan dan (2) mengidentifikasi suatu himpunan berikut definisi operasinya, apakah termasuk grupoid, semigrup, monoid atau grup beserta alasan logis, dimana untuk poin (2) ini, masing-masing kelompok diminta memberikan alasan jawaban 3 nomor, karena ada 7 kelompok agar tepat 21 nomor. Catatan untuk kelompok 4, bahwa kedua indikator pemahaman konsep grup dan sifat-sifatnya adalah $100 \%$, baik menyatakan ulang sifatsifat untuk suatu grup maupun mengidentifikasinya. 
Berikut gambar hasil kerja kelompok 4.

Halaman 1.

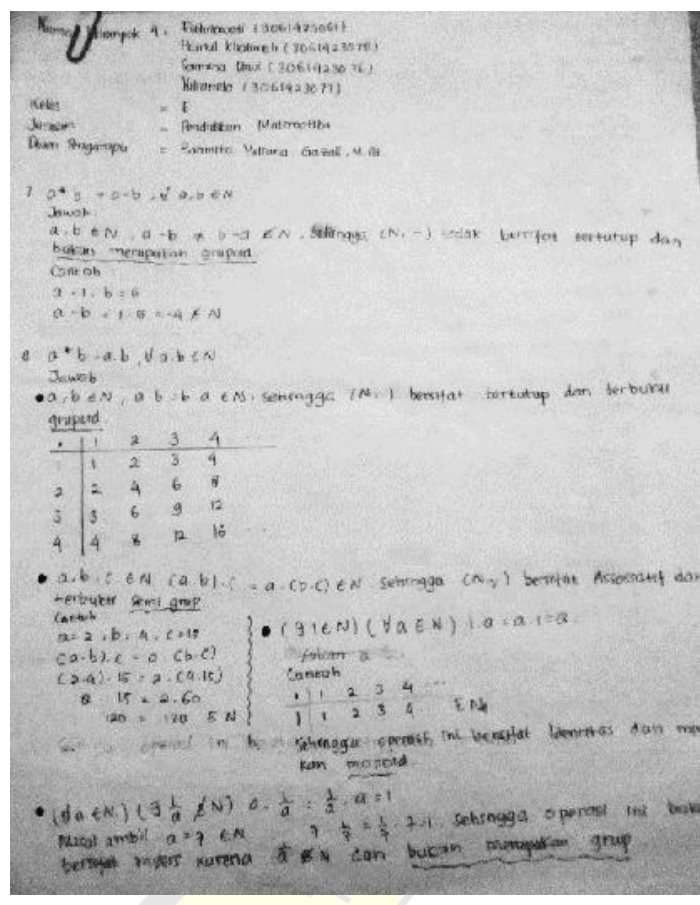

masalah yang ada di lembar kerja, dan tetap tinggal untuk menjelaskan kepada tamu tentang konsep grup dan sifat-sifatnya. Namun, hasil penelitian ini baru sebatas pemahaman secara mahasiswa secara berkelompok, belum pada kemampuan pemahaman mahasiswa secara individu.

\section{Aktivitas Mahasiswa}

Dalam penelitian ini, aktivitas mahasiswa yang diamati lebih kepada aktivitas yang ada pada langkah-langkah model pembelajaran kooperatif tipe TS-TS. Dari 28 mahasiswa yang mengikuti perkuliahan pada saat penelitian dilaksanakan, berikut persentase rata-rata aktivitas mahasiswa selama proses perkuliahan dengan model pembelajaran kooperatif tipe TS-TS yang tersaji pada Tabel 3.

Tabel 3. Rata-rata Persentase Aktivitas Mahasiswa saat Perkuliahan

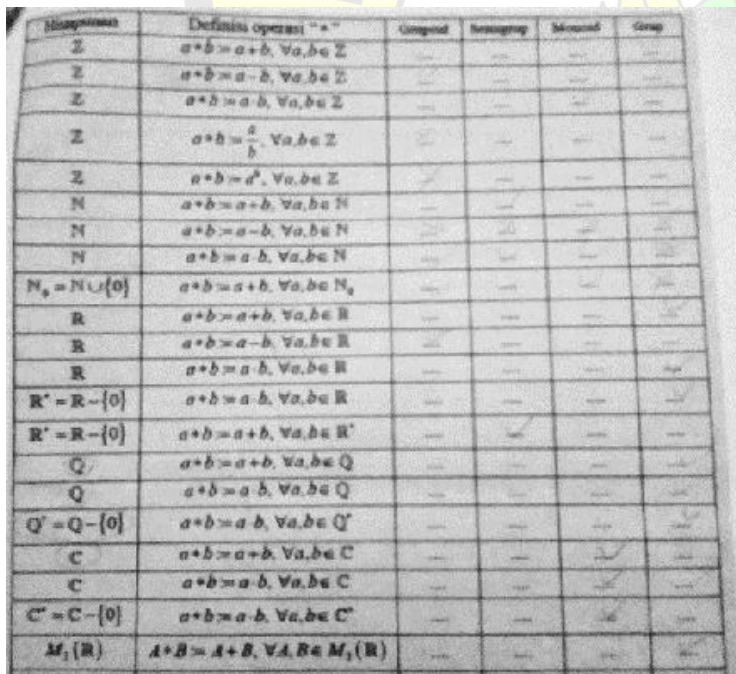

Halaman 2.

Secara umum, pemahaman mahasiswa tentang konsep grup dan sifat-sifatnya dilihat dari rata-rata di kedua indikator menunjukkan hasil yang baik. Ini dimungkinkan karena karakteristik model pembelajaran kooperatif tipe TS-TS memungkinkan mahasiswa untuk lebih memperdalam konsep grup dan sifatsifatnya, dengan bertamu menanyakan

\begin{tabular}{|c|c|c|}
\hline \multirow{4}{*}{$\begin{array}{l}\text { Bertanya kepada } \\
\text { dosen selama } \\
\text { proses } \\
\text { pembelajaran dan } \\
\text { diskusi }\end{array}$} & \multirow{4}{*}{21,4} & \\
\hline & & $\begin{array}{c}\text { Dari } 28 \\
\text { mahasiswa }\end{array}$ \\
\hline & & $\begin{array}{l}\text { tercatat hanya } 6 \\
\text { mahasiswa yang }\end{array}$ \\
\hline & & $\begin{array}{l}\text { bertanya kepada } \\
\text { dosen }\end{array}$ \\
\hline $\begin{array}{c}\text { Bertanya kepada } \\
\text { teman selama } \\
\text { proses }\end{array}$ & 92,9 & $\begin{array}{c}\text { Dari } 28 \\
\text { mahasiswa, } 27 \\
\text { aktif saling } \\
\text { menanyakan }\end{array}$ \\
\hline
\end{tabular}




$$
\begin{gathered}
\text { pembelajaran dan } \\
\text { diskusi } \\
\text { Mengerjakan } \\
\text { tugas secara } \\
\text { kelompok dan ikut } \\
\text { berdiskusi }
\end{gathered}
$$

Berpartisipasi dalam sistem kandang (stay) dan atau tandang

(stray)

Mempresentasikan hasil kerja kelompok terkait tugas kepada teman

Berdasarkan catatan, semua mahasiswa berdiskusi dalam kelompok dalam mengerjakan tugas

100

Semua mahasiswa berpartisipasi

Hanya 3 mahasiswa yang mempresentasikan hasil kerja kelompok, karena keterbatasan waktu

Berikut ini beberapa dokumentasi perihal aktivitas mahasiswa dalam beberapa indikator berikut.

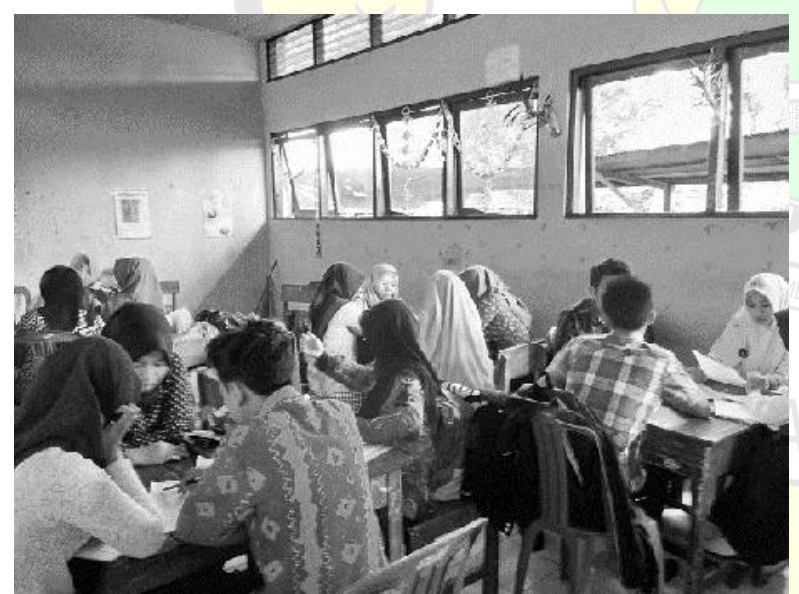

Aktivitas mengerjakan tugas secara kelompok dan diskusi

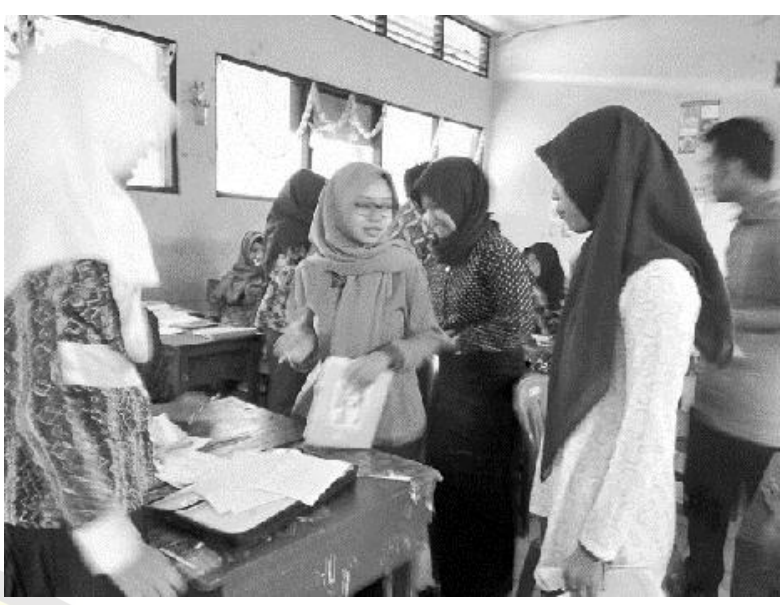

Aktivitas moving "stay" dan "stray"

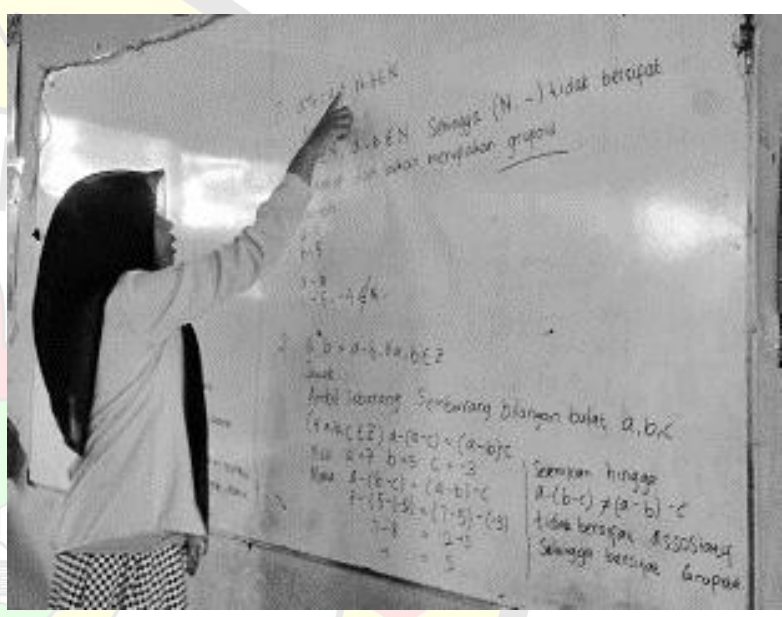

Aktivitas mempresentasikan hasil kerja kelompok

Secara umum, aktivitas mahasiswa tiap individu sesuai indikator hampir semua terpenuhi (beraktivitas), tetapi untuk indikator bertanya kepada dosen memang hanya sedikit. Hal ini diduga lebih nyaman bertanya kepada teman sebaya baik dalam kelompok maupun di luar kelompok dibandingkan bertanya kepada dosen karena segan atau ada perasaan yang kurang berani padahal ingin menanyakan karena ada yang belum dipahami. Sedangkan untuk indikator mempresentasikan hasil kerja kelompok, tidak semua mahasiswa karena hanya perwakilan di beberapa kelompok, karena keterbatasan waktu penelitian. 


\section{Pembahasan}

\section{A. Keterlaksanaan Perkuliahan dengan} Model Pembelajaran Kooperatif tipe TS-TS

Perkuliahan struktur aljabar pada materi grup dan sifat-sifatnya dengan model pembelajaran kooperatif tipe TS-TS berjalan dengan lancar dengan keterlaksanaan $100 \%$. Ini dimungkinkan karena mahasiswa di awal sebelum masuk ke materi pokok, dosen menjelaskan aturan main perkuliahan saat itu, yaitu akan menerapkan model pembelajaran kooperatif tipe TS-TS. Di level mahasiswa, ketika sudah dijelaskan tentang urutan/sintaks/langkah-langkah

pembelajarannya, maka tidak sulit bagi mahasiswa untuk memahami dan mengikuti alur pembelajaran.

\section{B. Pemahaman Mahasiswa tentang Grup dan sifat-sifatnya}

Pemahaman individu terhadap suatu konsep merupakan hasil dari aktivitas mental individu itu dalam memahami konsep yang dimaksud. Seseorang memahami suatu konsep karena telah melakukan aktivitas berpikir tentang konsep tersebut. Sementara itu, menurut Driver (Jafar, 2013, hal. 88) pemahaman adalah kemampuan menjelaskan suatu situasi atau suatu tindakan. Dari hal ini, pemahaman mengandung tiga komponen penting. Pertama, berkaitan dengan kemampuan mengenali atau mengidentifikasi unsur-unsur yang membangun obyek, situasi atau tindakan yang dimaksud. Kedua, berkenaan dengan kemampuan menjelaskan sifat-sifat esensial sebagai batasan dari obyek, situasi atau tindakan dimaksud, dan ketiga berkenaan dengan kemampuan menginterpretasi. Melalui model pembelajaran kooperatif tipe TS-TS, memungkinkan mahasiswa untuk lebih memahami mengenai konsep yang sedang atau telah dipelajari.
Minggi (2010, hal. 207) berpendapat bahwa pemahaman merupakan pengkaitan antara skema yang ada dengan informasi yang diterima. Artinya bahwa mahasiswa dikatakan memiliki pemahaman terhadap suatu konsep yang baik jika mahasiswa tersebut telah mampu memahami arti, situasi serta fakta yang diketahui dan mampu mengaitkan konsepkonsep yang baru diterima dengan konsepkonsep yang telah dimiliki sebelumnya. Untuk mata kuliah struktur aljabar ini, sebagai prasyaratnya adalah mahasiswa telah lulus mata kuliah teori himpunan, teori bilangan sehingga mampu mengaitkan antara konsepkonsep dalam mata kuliah tersebut dengan konsep baru pada mata kuliah struktur aljabar.

Mahasiswa dikatakan memahami konsep yang diberikan dalam pembelajaran jika mampu mengemukakan dan menjelaskan suatu konsep yang diperolehnya berdasarkan kata-kata sendiri tidak sekedar menghafal. Mahasiswa dikatakan memiliki pemahaman terhadap suatu konsep jika mahasiswa tersebut telah mampu memahami arti, situasi serta fakta yang diketahui dan mampu mengkaitkan konsep-konsep yang baru diterima dengan konsep-konsep yang telah dimiliki sebelumnya.

Pemahaman seorang individu terhadap suatu konsep merupakan hasil dari aktivitas mental individu itu dalam memahami konsep yang dimaksud. Seseorang memahami sesuatu konsep karena telah melakukan aktivitas berpikir tentang konsep tersebut. Skemp (1976, hal. 25) berpendapat bahwa "to understand something means to assimilate it into an appropriate schema". Hal ini mengandung arti bahwa seseorang dikatakan memahami sesuatu apabila telah terjadi pengintegrasian informasi baru dengan skema yang dimiliki orang tersebut. Artinya, untuk memperoleh pemahaman mendalam tentang 
suatu konsep, dapat dilihat dari kemampuan (ability) seseorang dalam pengintegrasian informasi baru melalui proses akomodasi dan asimilasi ke dalam skema yang dimiliki orang tersebut sebelumnya sehingga terbentuk skema baru.

Meskipun begitu, Rohana (2011, hal. 110-122) berpendapat bahwa dalam proses belajar mengajar, hal terpenting adalah bagaimana pencapaian pada tujuan yaitu agar mahasiswa mampu memahami sesuatu berdasarkan pengalaman belajarnya. Sehingga mahasiswa mampu memahami konsep-konsep matematika yang merupakan hasil konstruksi atau rekonstruksi terhadap obyek matematika. Artinya bahwa pemahaman konsep mahasiswa sangat penting diperhatikan karena pemahaman suatu konsep diperlukan untuk menjembatani pemahaman konsep berikutnya. Melalui model pembelajaran kooperatif tipe TS-TS yang karakteristiknya bertamu menanyakan informasi dan tinggal untuk menjelaskan informasi, mahasiswa mampu memahami tentang grup dan sifat-sifatnya lebih baik.

\section{Aktivitas Mahasiswa}

Aktivitas belajar mahasiswa terhadap Penerapan Model Pembelajaran Kooperatif Tipe Two Stay Two Stray (TS-TS) diukur dengan menggunakan lembar observasi, dengan hasil yang baik meskipun dua indikator masih relatif kurang aktivitas mahasiswanya. Namun, melalui penerapan model pembelajaran kooperatif tipe TS-TS ini sedikit banyak telah membuat aktivitas mahasiswa selama perkuliahan lebih bervariasi, tidak sekadar mencatat, mendengarkan penjelasan maupun tugas presentasi, tetapi berinteraksi dengan teman melalui sistem diskusi, bertanya.

Seperti pendapat dari Sanjaya (2007, hal.

249) bahwa dengan adanya pembelajaran kooperatif, mahasiswa tidak terlalu menggantungkan kepada dosen tetapi dapat menambah kemampuan berpikir sendiri dan menemukan informasi dari berbagai sumber, misalkan teman, meskipun dosen tetap sebagai fasilitatornya.

\section{Simpulan dan Saran}

\section{Simpulan}

Penerapan model pembelajaran kooperatif tipe TS-TS pada mata kuliah struktur aljabar di materi grup dan sifatsifatnya:

1. Memberikan pemahaman yang lebih mendalam tentang konsep grup dan sifatsifatnya dikarenakan karakteristik sistem kandang (stay) dan tandang (stray) yang memungkinkan mahasiswa untuk bertanya dan menjelaskan secara tidak langsung dapat memberikan pemahaman lebih dalam tentang konsep yang dipelajari.

2. Memperbanyak variasi aktivitas yang dilakukan mahasiswa saat perkuliahan, tidak hanya sekadar mencatat, mendengarkan penjelasan dosen, tetapi sharing bertanya jawab dengan teman maupun anggota kelompok.

\section{Saran}

Penelitian ini baru sebatas untuk mengetahui sekaligus mendeskripsikan tentang bagaimana penerapan model pembelajaran kooperatif tipe TS-TS dilaksanakan, terutama dalam dua sudut pandang yaitu pemahaman konsep yang dimiliki mahasiswa dan aktivitas mahasiswa. Oleh sebab itu, terbuka kemungkinan untuk penelitian lebih lanjut tentang pengaruh 
maupun bagaimana meningkatkan pemahaman melalui model, metode, pendekatan, maupun strategi pembelajaran yang tidak hanya diterapkan di jenjang sekolah tetapi juga jenjang perguruan tinggi.

\section{Daftar Pustaka}

Amir, Muhammad Faizal \& Machfud Indra Kurniawan. 2016. Penerapan Pengajaran Terbalik untuk Meningkatkan Hasil Belajar Mahasiswa PGSD UMSIDA pada Materi Pertidaksamaan Linier. Jurnal Pedagogia ISSN 2089-3833. Volume 5. No.1 Februari 2016 page 13-25.

Arnawa, I Made. 2009. Mengembangkan Kemampuan Mahasiswa dalam Memvalidasi Bukti pada Aljabar Abstrak melalui Pembelajaran Berdasarkan Teori APOS. Jurnal Matematika dan Sains 14(2): 62-68.

Darminto, Bambang, P. 2009. Upaya Peningkatan Pemahaman Konsep Aljabar dan Sikap Mahasiswa Calon Guru Matematika terhadap Pembelajaran Berbasis Komputer. Makalah dipresentasikan dalam Seminar Nasional Aljabar, Pengajaran dan Terapannya. Jurusan Pendidikan Matematika FMIPA UNY Yogyakarta.

http://teorionline.wordpress.com/

Jafar. 2013. Membangun Pemahaman yang Lengkap (Completely Understanding) dalam Pembelajaran Konsep Grup. KNPM V Himpunan Matematika Indonesia.
Minggi, Ilham. 2010. Proses Intuisi Mahasiswa dalam Memahami Konsep Limit Fungsi Berdasarkan Perbedaan Gender. Disertasi tidak diterbitkan. Surabaya: Universitas Negeri Surabaya.

Rohana. 2011. Pengaruh Pembelajaran Berbasis Masalah terhadap Pemahaman Konsep Mahasiswa Prodi Pendidikan Matematika FKIP Universitas PGRI Palembang. Prosiding Seminar Pendidikan. Universitas PGRI Palembang 27 Juni 2011.

Sanjaya, Wina. 2007. Kajian Kurikulum dan Pembelajaran. Bandung: Pascasarjana UPI

Sanjaya, Wina. 2013. Penelitian Pendidikan, Jenis, Metode, dan Prosedur. Jakarta: Kencana Prenada Media Group.

Skemp, R. 1976. Relational Understanding Mathematic Teaching. 77, 20-26. Online(http://www.grahamtall.co.uk/s kemp/pdfs/instrumental-relational.pdf, diakses 10 April 2017).

Sugiyono. 2005. Memahami Penelitian Kualitatif. Bandung: Alfabeta.

Suprijono, Agus. 2009. Cooperatif Learning Teori dan Aplikasi PAIKEM. Yogyakarta: PT Pustaka Pelajar.

Yusritawati. 2009. Pengaruh Penerapan Model Pembelajaran Kooperatif Teknik Two Stay Two Stray terhadap Kemampuan Representasi Matematika Siswa SMP. (Skripsi Jurusan Pendidikan Matematika FKIP UNPAS: 
tidak diterbitkan) diunduh dari http://furahasekai.wordpress.com/2011 /09/07/pembelajarankooperatif- tipetwo-stay-two-stray/ tanggal 10 April 2017 